than with the causes. Random samples of workers in factories were studied for periods of six weeks, at times of the year which were not affected by leave or annual holidays. The women worked on the threeshift system and the shifts were changed weekly. Analysis of the figures showed that, contrary to the general view, few women habitually lost one or more shifts each week, but a large majority were absent for varying lengths of time at irregular intervals. This suggests a study of the personal causes of absenteeism. Much of the absence was due to fullweek absence and this was mainly due to sickness. Married women lost more time than single women, and they also tended to have more longer and fewer shorter absences than single women. Absenteeism was highest on Saturday, and was lowest on pay-day. A factory that employed a very large number of women, and which had grown very rapidly and was situated in an isolated position, had a higher absence rate than one of more stable development and more advantageously placed. On the average it was found that there was little difference in absenteeism between women who took up to one hour to reach the factory, but above that limit absenteeism increased with travelling time.

\section{Bicentenary of Martin H. Klaproth (1743-1817)}

BorN on December 1, 1743, a few months after Lavoisier, Martin Heinrich Klaproth was the foremost chemist in Germany, and it was largely due to him that his fellow-workers in Berlin adopted the new theories of the French chemists in place of the phlogiston theory of their countryman Stahl. Klaproth was born in the small town of Wernigerode, in Upper Saxony. He was educated first for the Church. He began his life's work as an assistant in a laboratory at Quedlinburg, where he spent seven years. After short periods passed in Hanover and Dantzig, he entered the service at Berlin of the elder Valentin Rose (1736-71), the grandfather of the well-known chemists, Heinrich and Gustav Rose. His employer's early death in 1771 led him to set up a laboratory of his own and he afterwards gained a high reputation for his numerous and accurate analyses of minerals. His researches were regarded as a pattern for the rising generation of chemists, and to him we owe much of the early known facts about zirconium, uranium, tellurium, cerium, titanium and beryllium. He also prepared a mineralogical system, and with Friedrich Benjamin Wolf published the first German chemical dictionary. He held various public appointments; in 1788 he was elected a member of the Berlin Academy of Sciences, and when the University of Berlin was founded in 1809 by Wilhelm Baron von Humboldt, Klaproth was given the chair of chemistry. As a member of the Academy, he had in 1792 repeated the most important experiments of Lavoisier, and it was this that contributed to the spread of the new theories. He kept active to the last and died in Berlin on January 1, 1817, at the age of seventythree. His son, Heinrich Julius von Klaproth (1783-1835), was a distinguished Orientalist and traveller.

\section{Science Class Lecture Cine-Films}

A VERY successful film exhibiting the Brownian movement has recently been made in the Natural Philosophy Laboratory of the Royal Technical College, Glasgow, by Mr. Thomas S. Wylie, a former student of the College, in collaboration with Dr. Quintin Moore, of the Bacteriology Department. A dilute aqueous suspension of colloidal silver particles of order $50 \mathrm{~m} \mu\left(50 \times 10^{-7} \mathrm{~cm}\right.$.) diameter was viewed with the aid of a 'Cardioid' ultra-microscopic condenser in conjunction with a microscopic combination magnifying about 1,200 times. The film was photographed through the eyepiece of the microscope. This is an excellent example of a really useful application of cine-photography to the experimental illustration of a science class lecture. In order that the students of a large class can observe individ. ually the Brownian movement under the microscope, it is necessary to have the apparatus set up on many successive meetings of the class. With this film the whole class can observe the motions in a matter of three or four minutes. Mr. Wylie has also made an interesting film which, in a time of about ten minutes, shows the following surface tension experiments, some of which are difficult to set up and manipulate: (a) formation of a drop with the subsequent Plateau's spherule ; (b) camphor movements on a clean water surface ; $(c)$ the beating 'mercury heart'; and $(d)$ the difference in pressure in large and small bubbles.

\section{Do All Statements Make Predictions?}

IN the July issue of Mind, Mr. John Wisdom, under the title of "Other Minds (VII)", continues his lengthy philosophical dialogue dealing with our knowledge of other minds. In this episode his three interlocutors, Black, White and Gray, expound in that strange, obscure, slang-ridden, ungrammatical English which Mr. Wisdom affects, a theme which merits the attention of all interested in the problems of epistemology. The theme is simple: "what makes a statement objective also makes it predictive". It would be impossible in a few words to review the subtle analysis, the fine distinetions, which emerge from Mr. Wisdom's variations on this theme. Every kind of statement which might claim merely to report present fact and not to predict anything is brought to the bar and convicted of lurking predictiveness. The knowledge expressed in the statement "I am in pain" is finally admitted to be not predictive, but it is alleged to be.a queer kind of knowledge because we cannot conceive what it would be to be wrong on such a matter. Again, speaking of statements such as "All men are mortal" the author says : "They become more really knowable, more necessarily true, the fewer future facts can make them fail, and they become quite knowable and quite necessarily true only when no future fact can make them fail". This is what America's greatest philosopher, Charles Sanders Peirce, said forty years ago. It has not ceased to be true, and Mr. Wisdom embroiders its expression with many illuminating subtleties of thought.

\section{Some Old Letters of Astronomical Interest}

IN an article entitled "An Eighteenth Century Correspondence" in the October issue of the Observatory $(65,92$; 1943), Prof. H. C. Plummer reports on the contents of a collection of old letters received by Nathaniel Pigott and lately presented to the Royal Astronomical Society. Nathaniel (c. 1740-1804) was the father of Edward Pigott, who discovered the variability of $\eta$ Aquilæ. $\mathrm{He}$ was himself greatly interested in astronomy, making observations of a partial eclipse of the sun in 1765 and of the transit 